\title{
Factors influencing brand switching behaviour among Indian youth: An empirical study of mobile service providers
}

\author{
Manjit Singh $^{1}$, Sanjeev Bansal ${ }^{2 *}$ \\ ${ }^{1}$ Professor, ${ }^{2}$ Research Scholar, Dept. of Management, Sant Longowal Institute of Engineering and Tech., Longowal, Punjab, India \\ *Corresponding Author: Sanjeev Bansal \\ Email: sbansal.sliet@gmail.com
}

\begin{abstract}
This study examined the factors which influence brand switching behavior among customers regarding their mobile phone service providers. The four factors Service Quality, Price, Trust and Brand Image identified on the basis of previous studies were analyzed to know the effect on brand switching behavior of customers. For the purpose of this study a sample of 200 students from different colleges situated in the district Bathinda of Punjab state were chosen as respondent. Multiple regression method is used to analyze the relationship between brand switching behavior (Dependent Variable) and service quality, price, trust and brand image as (Independent Variable).
\end{abstract}

Keywords: Brand switching, Service quality, Brand image.

\section{Introduction}

India is the world's second largest telecommunication market with around 1.19 billion subscribers as October 2018. The telecom market can be split into three segmentswireless, wireline and internet services. The wireless market dominates comprises $98.15 \%$ percent of the total subscriber base as of October 2018. India is also the second largest country in terms of internet subscribers with 560.01 million internet subscribers as of September 2018. India became the world's fastest growing market for mobile application in the first quarter of 2018 and remained as the world's fastest growing market for Google Play downloads in the second and third quarter of 2018.

The mobile service providers experienced an exponential growth in the last 15 years. The mobile phone has now become a mass market, every communication tool for all type of customers, from being an exclusive and expensive electronic device, at the start of millennium. The market is entering into maturity stage after remaining in the growth stage during the last decade, seeing a phenomenal growth's expectation of the customers have been growing on one hand and unprecedented technological breakthrough have led the industry into burgeoning costs toward infrastructure development. The industry is facing the following threats:-

1. Hyper competitive environment.

2. Decrease in average Minutes of usage and Decrease in average Revenue per user(ARPU)

3. Increase in operational expenses.

The pressure of rolling out new technology is also impacting heavily on the companies. The subscribers are switching frequently from one network to another. The problems are handled by the operators presently by adopting different strategies i.e. by increasing the mobile customers or retaining the existing customers etc.

The subscribers switching for the service providers have become the major issue before the companies in order to survive this hyper competitive market, which otherwise provide a lot of avenues.
Consumer behavior is the study of the various psychological, social, anthropological, economic, demographic, etc. factors that influence a consumer's decision while purchasing a product. It is used to analyses the characteristics of consumers, to predict and understand their needs. The key consumer behavior factors are personal influences like those by friends and family, users of the product and social influences like class, status symbol, occupation, education which play an important role in brand switching. In marketing and micro economics, customer/consumer switching behavior means customer/consumer abandoning a product or service in favor of a competitor. Brand switching as opposed to brand loyalty is the outcome of customer switching behavior.

Brand switching can be explained as the decision of a consumer to purchase a product of brand different from the current brand used by him. It may be induced by either extrinsic or intrinsic factors. Extrinsic factors mostly include sales promotions, discounts, advertisements, popularity, cost, etc. while intrinsic factors may include boredom, curiosity, desire to try a new brand, etc.

\section{Literature Review}

Kollman (2000), Satish et al (2011), Kotler and Armstrong (2010) found that price is the most important factor which influences consumer purchase decision. Ashraf et al (2013) explained the importance of net quality, service quality, leverage, coverage voice clarity etc. Ventis and Ghauri (2000), Serken and Gorhan (2004), Fuha (2005) and Kabir et al (2009) emphasized that service quality is considered a positive driver for behavior intention of leaving, switching or retaining. Charles et al (2011) the ultimate objective of any company is to gain customer satisfaction in order to retain them form long switching cost.

\section{Research Methodology}

The objective of the study is to analyze the factors which encouraged brand switching among customers in telecommunication sector. Primary data is used for the study and the data for this research was gathered through use of 
Table 1

\begin{tabular}{|c|c|c|c|c|c|c|}
\hline \multicolumn{7}{|c|}{ Coefficients } \\
\hline \multirow{2}{*}{\multicolumn{2}{|c|}{ Model }} & \multicolumn{2}{|c|}{ Un-Standardized } & \multirow{2}{*}{$\frac{\text { Standardized }}{\text { Beta }}$} & \multirow[t]{2}{*}{$\mathbf{t}$} & \multirow[t]{2}{*}{ Sig. } \\
\hline & & B & Std. Error & & & \\
\hline \multirow[t]{5}{*}{1} & Constant & & 1.128 & .404 & 2.561 & .009 \\
\hline & Service Quality & .382 & .147 & .239 & 2.975 & .006 \\
\hline & Price & .067 & .051 & .064 & .873 & .356 \\
\hline & Trust & .352 & .091 & .439 & 4.370 & .000 \\
\hline & Brand Image & -.441 & .149 & .298 & -2.339 & .01 \\
\hline
\end{tabular}

structured questionnaire which was duly filled by 200 participants from Bathinda city. The participants were students from various colleges situated in Bathinda. The Regression Analysis was applied in order to test research hypothesis. The factors which affect significantly switching behaviour have been identified on the basis of previous studies and are given below:

1. Price

2. Service quality

3. Brand image

4. Trust

\section{Hypothesis}

H1: Price is positively associated with brand switching behavior.

H2: Service quality is negatively associated with Brand Switching.

H3: Brand Image has negative impact on brand switching behavior.

H4: Trust has a negative impact on brand switching behavior.

\section{Regression Model}

$\mathbf{Y}=\mathrm{a}+\mathrm{bx}_{1}+\mathrm{cx}_{2}+\mathrm{dx}_{3}+\mathrm{ex}_{4}+\mathrm{e}$

\section{Where}

Dependent Variable is

$\mathbf{Y}=$ Brand Switching Behaviour

And Independent Variables are
a) $\mathrm{a}=$ Intercept
b) $\mathrm{x}_{1}=$ Service Quality
c) $x_{2}=$ Price
d) $\mathrm{x}_{3}=$ Trust
e) $\mathrm{x}_{4}=$ Brand Image
f) $\mathrm{e}=$ Error Term

\section{Limitation of the Study}

The present research is limited in its scope as it assessed the influence of four variables on consumer intention to switch to new service providers and limited to mobile service providers situated in Bathinda only. It is limited in terms of predictive power of research but still it offers an insight into possible reasons for switching behaviour among customers in telecommunication industry.

\section{Results}

The model Summary tells us that how much our table our model is fit. The value of Adjusted R Square which is .450 which explains that all the independent variables together explain the variation in dependent variable i.e. brand switching.

\section{Model Summary}

\begin{tabular}{|c|c|c|c|c|}
\hline Model & $\mathbf{R}$ & $\begin{array}{c}\text { R } \\
\text { Square }\end{array}$ & $\begin{array}{c}\text { Adjusted } \\
\text { R Square }\end{array}$ & $\begin{array}{c}\text { Standard } \\
\text { Error of the } \\
\text { Estimate }\end{array}$ \\
\hline 1 & $.631 \mathrm{a}$ & .483 & .450 & .752 \\
\hline
\end{tabular}

a. Predictors: (Constant), Brand Image, Service Quality, Price, Trust

Actual significant value is 0.05 and this table shows the sig value of 0.00 so according to it sig value $0.00<0.05$ which shows that there is an association between the dependent variable, Brand switching and the independent variables, Service Quality, Price, Trust and Brand Image.

\section{Conclusion}

This study has been conducted to know the different factors i.e. service quality. Price. Trust and brand image (identified on the basis of previous studies), which influence customers to switch brand in cellular networks. The various results of correlation and regression analysis shows that:

1. Rejection of the $\mathrm{H} 1$ and study indicated the positive relation of service quality with the brand switching behaviour. Though the quality service is provided but still customer shift to other service provider.

2. $\mathrm{H} 2$ is accepted as the result indicates the positive relation between the Brand switching and price. Higher the price, higher switching and vice versa.

3. This study also rejected $\mathrm{H} 3$ that brand switching has negative relation with Trust. The result indicates the positive association of trust with brand switching.

4. The study supported $\mathrm{H} 4$ that brand image has a negative impact on brand switching.

\section{Conflict of Interest: None.}

\section{References}

1. Ashraf. Determinants of customer satisfaction: The case of Pakistan telecommunication industry. J Basic Appl Res 2013;3(1):251-8.

2. Fuha M. Dynamics of price sensitivity among mobile service customers. J Product and Brand Manag 2005;14(1):65-73.

3. Kabir. The factors determining customer satisfaction and loyalty: Study of mobile telecommunication industry in Bangladesh, ASA University Review, 2009;3(2):147-56. 
4. Kollmann T. The Price/Acceptance Function: Perspectives of a Pricing Policy in European Telecommunication Markets. Eur J Innov Manage 2000;3(1):7-14.

5. Kothari R., Sharma A, Rathore J. Service quality in cellular mobile services: An empirical study of cellular mobile users. Vidwat 2011;4(1):11-20.

6. Kotler P. and G. Armstrong (2010), Principles of Marketing. 13th Edition., New Jersey: Prentice Hall.

7. Satish. A study on consumer switching behavior in cellular service provider: A study with reference to Chennai. Far East J Psychol Business 2011;71-81.
8. Serkan A and Gorhan O. The analysis of antecedents of customer loyalty in Turkish mobile telecommunication markets. Eur J Marketing 2004;39:910-25.

How to cite this article: Singh M, Bansal S. Factors influencing brand switching behaviour among Indian youth: An empirical study of mobile service providers. J Manag Res Anal 2019;6(2):98-100. 